\title{
Pengaruh Faktor Sosial Ekonomi Dan Materialism pada Personal Financial Behavior melalui Financial Literacy Mahasiswa Akuntansi
}

\author{
Luh Gede Krisna Dewi ${ }^{1}$ \\ Fakultas Ekonomi dan Bisnis \\ Universitas Udayana, Indonesia \\ Email: gede_krisna@unud.ac.id
}

\author{
Made Yenni Latrini ${ }^{2}$ \\ Fakultas Ekonomi dan Bisnis \\ Universitas Udayana, Indonesia
}

\begin{abstract}
ABSTRAK
Penelitianini bertujuan untuk menemukan bukti empiris pengaruh faktor sosial ekonomi dan materialism pada personal financial behavior mahasiswa akuntansi melalui tingkat financial literacy mahasiswa. Sampel penelitian adalah 67 mahasiswa akuntansi dan yang ditentukan dengan metode purposive sampling. Penelitian ini menggunakan teknik analisis jalur. Hasil penelitian ini menemukan variabel financial literacy mampu memediasi hubungan antara status sosial ekonomi orang tua mahasiswa pada personal financial behavior. Status sosial dan sikap materialism juga menjadi factor yang mempengaruhi tingkat financial literacy dan personal financial behavior mereka. Implikasi dari penelitian ini a dalah untuk mengembangkan kurikulum pendidikan dan pola pembelajaran terkait dengan faktor sosial ekonomi dan materialism yang mempengaruhi personal financial behavior mahasiswa akuntansi melalui tingkat financial literacy yang dimiliki.
\end{abstract}

Kata Kunci: Personal Financial Behavior; Status Sosial Ekonomi; Materialism; Financial Literacy.

\section{Effect of Socio-Economic Factors and Materialism on Personal Financial Behavior through Financial Literacy of Accounting Students}

\begin{abstract}
The aims of this study is to analyze and to find empirical evidence of the influence of socio-economic factors and materialism on the personal financial behavior of accounting students through their level of financial literacy. The research sample is accounting students at Bukit Jimbaran Campus determined using purposive sampling method. From the sampling process, 67 respondents completed the questionnaire. This study uses path analysis techniques (path analysis). The results of this study found that the financial literacy variable was able to mediate the relationship between the parents' socio-economic status on the pattern of personal financial behavior of accounting students. Social status and materialism attitudes also become factors that influence the level of financial literacy of students and their personal financial behavior. The implications of this research are expected to be useful for educational institutions to develop educational curricula and learning patterns related to socio-economic factors (parent status or income) and psychological factors (materialism) in influencing personal financial behavior of accounting students through the financial literacy level.
\end{abstract}

Keywords: Personal Financial Behavior; Socio-Economic Factors; Materialism; Financial Literacy.

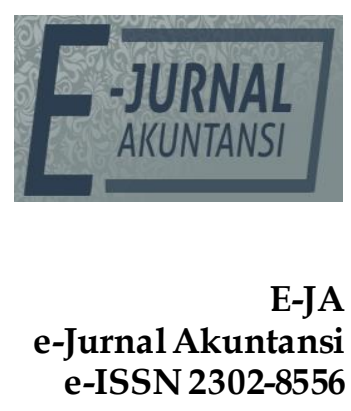

Vol. 30 No. 6

Denpasar, Juni 2020

Hal.1575-1592

Artikel Masuk: 13 Januari 2020

Tanggal Diterima: 23 Juni 2020

The Article is Available in: https://ojs.unud.ac.id/index.php/Akuntansi/index 


\section{PENDAHULUAN}

Perkembangan global sekarang ini berpengaruh pada berbagai kemudahan dalam bertransaksi dan pengelolaan keuangan. Masyarakat dihadapkan pada berbagai macam pilihan untuk pengelolaan keuangan. Dengan menerapkan cara pengelolaan keuangan yang benar, maka seseorang diharapkan bisa mendapatkan manfaat yang maksimal dari uang yang dimilikinya (Widyawati, 2012). Untuk itu sangat penting untuk memiliki kemampuan mengelola keuangan (financial management). Manajemen keuangan pribadi merupakan salah satu aplikasi dari konsep manajemen keuangan pada level individu. Manajemen keuangan yang meliputi aktivitas perencanaan, pengelolaan dan pengendalian keuangan, sangatlah penting untuk mencapai kesejahteraan finansial. Aktivitas perencanaan meliputi kegiatan untuk merencanakan alokasi pendapatan yang diperoleh akan digunakan untuk apa saja. Pengelolaan merupakan kegiatan untuk mengatur atau mengelola keuangan secara efisien sedangkan pengendalian merupakan kegiatan untuk mengevaluasi apakah pengelolaan keuangan sudah sesuai dengan yang direncanakan atau dianggarkan (Laily, 2016).

Kemampuan mengelola keuangan pribadi juga penting bagi mahasiswa. Mahasiswa memiliki masalah keuangan yang kompleks karena sebagian besar mahasiswa belum memiliki pendapatan serta cadangan dana yang juga terbatas untuk digunakan setiap bulannya. Mereka masih bingung dalam menentukan kebijakan keuangannya. Banyak alasan mahasiswa tidak dapat secara bijaksana mengatur keuangannya disebabkan karena kebanyakan belum memiliki pendapatan sendiri, serta cadangan dana yang terbatas untuk digunakan setiap bulan. Bagi mahasiswa, mengelola keuangan pribadi bukanlah hal mudah untuk dilakukan sebab ada saja kesulitan-kesulitan yang dihadapi, salah satunya adalah fenomena perilaku yang konsumtif yang berkembang sekarang ini.

Beberapa penelitian terdahulu menemukan jika personal financial behavior dipengaruhi oleh faktor-faktor psikologi seperti materialism (material value) (Nye \& Hillyard, 2013), faktor sosial ekonomi seperti status sosial dan pendapatan orang tua (Aningsih \& Soejoto, 2018), (Herawati, Candiasa, Yadnyana, \& Suharsono, 2018), dan (Widyawati, 2012), faktor demografi seperti gender, usia (Laily, 2016) dan faktor tingkat pengetahuan atau literasi keuangan dan kemampuan akademik mahasiswa (Herdjiono \& Damanik, 2016) dan (Laily, 2016).

Penelitian ini akan menganalisis pola personal financial behavior mahasiswa khususnya mahasiswa akuntansi yang dipengaruhi oleh status sosial ekonomi orang tua, materialism dan tingkat financial literacy yang dimiliki oleh mahasiswa. Personal financial behavior adalah kemampuan seseorang dalam mengatur (perencanaan, penganggaran, pemeriksaan, pengelolaan, pengendalian, pencarian dan penyimpanan) dana keuangan sehari-hari. Dalam praktiknya personal financial behavior terdiri dari tiga aktivitas utama yakni konsumsi, tabungan, dan investasi (Case, 2007), (Mankiw, 2003) dan (Noor, 2009). Grohmann, Kouwenberg, \& Menkhoff (2015) menyebutkan bahwa ada tiga faktor utama yang mempengaruhi personal financial behavior yakni financial literacy, kemampuan perhitungan (numeracy), dan kualitas pendidikan. 
Beberapa faktor diduga memiliki pengaruh langsung dan tidak langsung pada kemampuan individu mengelola keuangan. Salah satu faktor tersebut adalah status sosial ekonomi orang tua mahasiswa. Status sosial ekonomi orang tua yang diukur dari pendapatan atau income orang tua memberikan arah pendidikan pengelolaan keuangan di dalam keluarga (Widyawati, 2012). Perbedaan status sosial ekonomi orang tua membawa perbedaan yang besar dalam pengasuhan anak. Anak-anak dikondisikan oleh posisi subkultur dan kelas sosial ekonomi yang pada gilirannya mempengaruhi kognisi dan perilaku mereka. Pengetahuan seseorang tentang keuangan (financial literacy) sangat erat hubungannya dengan faktor kekayaan (wealth) dan tingkat pendidikan orang tua (Lusardi, Mitchell, \& Curto, 2010). Sehingga diduga status sosial ekonomi orang tua mahasiswa memiliki pengaruh langsung pada personal financial behavior dan berpengaruh tidak langsung pada personal financial behavior dengan dimediasi oleh tingkat financial literacy mahasiswa.

Selanjutnya faktor psikologi turut mempengaruhi personal financial behavior mahasiswa akuntansi. Pengaruh psikologis seperti sifat dan karakter merupakan faktor terkuat yang mempengaruhi perilaku keuangan seseorang (Suryanto, 2017). Salah satu sifat dan karakter yang menonjol dari manusia modern adalah materialism. Materialism adalah pernyataan tujuan hidup dan keinginan yang utama dalam bentuk kepemilikan dan perolehan barang-barang material (Richins, 2004). Penelitian Richins \& Dawson (1992) mengggambarkan materialism adalah nilai utama dalam mengarahkan perilaku dan pengambilan keputusan individu dalam menjalani kehidupan. Individu yang cenderung materialism meletakkan nilai yang berlebihan pada aspek materil dan lemah dalam membangun hubungan interpersonal dengan orang lain. Dalam konteks kehidupan modern, mahasiswa cenderung memiliki pola hidup yang konsumtif yakni mengkonsumsi barang-barang yang tidak dibutuhkan demi dapat menunjukkan prestise dalam pergaulan (Suryanto, 2017). Pola hidup yang terbentuk akan menjadi kebiasaan dan mempengaruhi tingkat financial literacy mahasiswa dan pada akhirnya mempengaruhi personal financial behavior mereka.

Planned Behavior Theory (TPB) telah banyak diaplikasikan untuk memahami bagaimana individu berperilaku dan bagaimana cara menunjukkan reaksi. Teori ini merupakan salah satu teori psikologi sosial yang memprediksi perilaku manusia. Alasan utama perilaku pengambilan keputusan merupakan hasil dari proses reasoning yang dipengaruhi oleh sikap, norma dan pengendalian perilaku. Lebih lanjut, Somer (2011) mengatakan bahwa perilaku manusia bisa disebabkan oleh alasan-alasan atau kemungkinan yang berbeda, hal ini berarti bahwa keyakinan seseorang tentang konsekuensi dari sikap dan perilaku, keyakinan akan ekspektasi terhadap orang lain dan adanya faktor-faktor yang mungkin menghalangi perilaku tersebut. Teori ini menunjukkan bahwa latar belakang seperti gender, usia, pengalaman, pengetahuan akan mempengaruhi keyakinan seseorang terhadap sesuatu yang pada akhirnya akan mempengaruhi perilaku seseorang tersebut (Ajzen, 1991). Teori planned behavior sesuai digunakan untuk mendeskripsikan perilaku apapun yang memerlukan perencanaan. Teori ini memiliki fondasi terhadap perspektif kepercayaan yang mampu mempengaruhi seseorang untuk melaksanakan tingkah laku yang spesifik. Perspektif kepercayaan dilaksanakan melalui penggabungan beraneka ragam karakteristik, 
kualitas dan atribut atas informasi tertentu yang kemudian membentuk kehendak dalam bertingkah laku.

Indikator status sosial ekonomi menurut Soekanto (2010) adalah pendidikan, pekerjaan, pendapatan, dan kepemilikan atau kekayaan (wealth). Latar belakang orang tua, pekerjaan orang tua, jabatan sosial orang tua dapat mempengaruhi sikap seseorang dalam melakukan kegiatan belanja, menabung, investasi, kredit, penganggaran, dan pengelolaan keuangan. Penelitian Aningsih \& Soejoto (2018) menemukan bahwa tingkat literasi seseorang dipengaruhi oleh tingkat pekerjaan dan status sosial orang tua. Berdasarkan pemaparan tersebut maka dapat dirumuskan hipotesis penelitian sebagai berikut:

$\mathrm{H}_{1}$ : Semakin tinggi status sosial ekonomi orang tua mahasiswa maka semakin tinggi tingkat financial literacy yang dimiliki mahasiswa.

Materialism merupakan nilai penting yang mempengaruhi hidup dan pengambilan keputusan individu. Materialism juga diartikan sebagai nilai-nilai sentral yang menuntun individu dalam berperilaku dan mengambil keputusan dalam kehidupan sehari-hari (Richins, 2004). Sifat materialistis yang dimiliki individu menyebabkan seseorang untuk cenderung memperkaya dirinya sendiri dengan cara terus menerus menumpuk kekayaan. Tindakan untuk mengumpulkan kekayaan dan memperkaya diri sendiri merupakan wujud refleksi dari suatu kesuksesan, kebahagian dan kenikmatan dunia. Sehingga individu akan berusaha untuk mempelajari dan menambah pengetahuan keuangan yang bermanfaat bagi pengambilan keputusan keuangan. Berdasarkan pemaparan tersebut maka dapat dirumuskan hipotesis penelitian sebagai berikut:

$\mathrm{H}_{2}$ : Semakin tinggi sifat materialism mahasiswa maka semakin tinggi tingkat financial literacy yang dimiliki mahasiswa.

Literasi keuangan erat kaitannya dengan manajemen keuangan dimana semakin tinggi tingkat literasi keuangan seseorang maka makin baik pula manajemen keuangan seseorang tersebut (Laily, 2016). Chinen \& Endo (2012) mengatakan bahwa individu yang memiliki kemampuan untuk membuat keputusan yang benar tentang keuangan tidak akan memiliki masalah keuangan dimasa depan dan menunjukkan perilaku keuangan yang sehat serta mampu menentukan prioritas kebutuhan bukan keinginan. Berdasarkan pemaparan tersebut maka dapat dirumuskan hipotesis penelitian sebagai berikut:

$\mathrm{H}_{3}$ : Semakin tinggi tingkat financial literacy mahasiswa akuntansi maka semakin baik personal financial behavior mahasiswa tersebut.

Faktor sosial ekonomi orang tua mahasiswa salah satunya dapat diukur dengan besarnya pendapatan (income) yang diperoleh dari gaji, upah dan penghasilan usaha lainnya. Pendapatan orang tua memengaruhi pengeluaran mahasiswa Herdjiono \& Damanik (2016). Orang tua berpendapatan lebih tinggi cenderung lebih banyak memberikan kontribusi pada pembayaran kuliah maupun tabungan anaknya. Selain itu, terdapat kemungkinan yang lebih besar individu dengan sumber dana (income) yang tersedia akan menunjukkan perilaku manajemen keuangan yang lebih bertanggung jawab, mengingat dana (income) yang tersedia memberi mereka kesempatan untuk bertindak secara bertanggung jawab (Ida \& Dwinta, 2010). Berdasarkan pemaparan tersebut maka dapat dirumuskan hipotesis penelitian sebagai berikut: 
$\mathrm{H}_{4}$ : Semakin tinggi status sosial ekonomi orang tua mahasiswa semakin baik personal financial behavior yang dimiliki mahasiswa tersebut.

Penelitian terdahulu Nye \& Hillyard (2013) menemukan bahwa sifat materialism erat kaitannya dengan pola konsumsi yang tidak direncanakan (impulsive consumption) sehingga individu dengan tingkat materialism tinggi akan cenderung mengalami masalah keuangan. Namun hasil yang berbeda dikemukakan oleh Darpito \& Anwar (2015), dimana sifat materialistis yang dimiliki individu menyebabkan seseorang untuk cenderung memperkaya dirinya sendiri dengan cara terus menerus menumpuk kekayaan. Tindakan untuk mengumpulkan kekayaan dan memperkaya diri sendiri merupakan wujud refleksi dari suatu kesuksesan, kebahagian dan kenikmatan dunia. Sehingga hal ini mempengaruhi tindakan individu dalam melakukan pengelolaan keuangan dengan lebih cermat dan hati-hati. Berdasarkan pemaparan tersebut maka dapat dirumuskan hipotesis penelitian sebagai berikut:

$\mathrm{H}_{5}$ : Semakin tinggi sifat materialism mahasiswa maka semakin baik personal financial behvior yang dimiliki mahasiswa tersebut.

Pembentukan literasi finansial dapat dilakukan melalui lingkungan keluarga maupun lingkungan perguruan tinggi (Widyawati, 2012). Di dalam lingkungan keluarga, tingkat literasi finansial ditentukan oleh peran orang tua dalam memberikan dukungan berupa pendidikan keuangan dalam keluarga. Pendidikan pengelolaan keuangan di dalam keluarga dipengaruhi oleh status sosial ekonomi orang tua dalam hal ini adalah besarnya pendapatan orang tua. Berdasarkan pemaparan tersebut maka dapat dirumuskan hipotesis penelitian sebagai berikut:

$\mathrm{H}_{6}$ : Semakin tinggi status sosial ekonomi orang tua mahasiwa maka personal financial behavior mahasiswa semakin baik melalui peningkatan financial literacy mahasiswa.

Materialism mendorong individu untuk lebih cermat dalam pengelolaan keuangan serta memberikan stimulus bagi mereka untuk menambah pengetahuan terkait dengan keuangan seperti pengetahuan umum keuangan, tabungan dan pinjaman, asuransi dan investasi. Sehingga sifat materialism berkaitan dengan perilaku keuangan sehat. Berdasarkan pemaparan tersebut maka dapat dirumuskan hipotesis penelitian sebagai berikut:

$\mathrm{H}_{7}$ : Semakin tinggi sifat materialism maka personal financial behavior mahasiswa semakin baik melalui peningkatan financial literacy.

\section{METODE PENELITIAN}

Penelitian ini menggunakan mahasiswa akuntansi regular sebagai sampel karena mahasiswa akuntansi merupakan calon profesional dalam bidang akuntansi dan keuangan. Pengambilan sampel (sampling) dari populasi yang ada dilakukan secara purposive sampling dengan tujuan mendapatkan sampel yang representatif sesuai dengan kriteria yang ditentukan.

Personal financial behavior adalah kemampuan seseorang dalam mengatur yaitu perencanaan, penganggaran, pemeriksaan, pengelolaan, pengendalian, pencarian dan penyimpanan dana keuangan sehari-hari. Indikator tersebut selanjutnya diukur dengan kuesioner yang diadaptasi dari penelitian Danes \& 
Haberman (2007) yang meneliti tentang personal financial behavior remaja. Ada 8 item pernyataan untuk mengukur variabel ini, dan diukur menggunakan skala Likert 5 poin (dari “tidak pernah" dengan skor 1 sampai “selalu” dengan skor 5). Indikator status sosial ekonomi menurut Soekanto (2010) adalah pendidikan, pekerjaan, pendapatan, dan kepemilikan/kekayaan. Status sosial ekonomi orang tua mahasiswa akan dikategorikan berdasarkan jumlah penghasilan orang tua mahasiswa perbulan yang berasal dari gaji, upah dan penghasilan usaha. Tingkat pendapatan dapat dikelompokkan menjadi empat golongan yaitu:

Tabel 1. Golongan Pendapatan Per Bulan

\begin{tabular}{lll}
\hline No & Tingkat Pendapatan per bulan & Kategori/Golongan \\
\hline 1. & < Rp. $1.500 .000,00$ & Rendah \\
2. & Rp. $1.500 .000,00-$ Rp. $2.400 .000,00$ & Sedang \\
3. & Rp. $2.500 .000,00-$ Rp. $3.500 .000,00$ & Tinggi \\
4. & > Rp. 3.500.000,00 & Sangat Tinggi \\
\hline
\end{tabular}

Sumber: Badan Pusat Statistik, 2019

Menurut Richins (2004) materialism adalah pernyataan tujuan hidup dan keinginan yang utama dalam bentuk kepemilikan dan perolehan barang-barang material. Sifat materialism individu dapat diukur dengan menggunakan Material Value Scale (MVS) yang dikembangkan oleh Richins (2004) dalam bentuk 16 item pernyataan dan diukur dengan skala Likert 5 poin.

Indikator literasi finansial ini meliputi pengetahuan umum, tabungan dan pinjaman, asuransi, serta investasi. Indikator tersebut selanjutnya diukur dengan pertanyaan dalam kuesioner dan selanjutnya dinilai jumlah jawaban yang benar dari responden. Ada 3 kategori tingkat financial literacy menurut Chen \& Volpe (1998) yakni tinggi, sedang, rendah. Pengkategorian ini didasarkan pada presentase jawaban responden yang benar dari sejumlah pertanyaan yang digunakan untuk mengukur literasi keuangan.

Data yang digunakan dalam penelitian ini adalah data kualitatif yakni data berupa kata-kata, kalimat, dan gambar. Data kualitatif yang terkait dengan penelitian ini adalah hasil kuesioner. Metode pengumpulan data adalah dengan observasi dan survey. Teknik analisis data yang digunakan dalam penelitian ini adalah analisis jalur (path analysis). Teknik analisis ini digunakan untuk mencari pengaruh langsung dan tidak langsung variabel independen pada variabel dependen melalui variabel mediasi. Dalam mengolah data dan mendapatkan hasil analisis menggunakan SPSS dan selanjutnya menghitung nilai Sobel (Z) untuk menentukan pengaruh tidak langsung dan peran variabel mediasi dalam model penelitian. Jika nilai Sobel $(Z)>$ nilai $Z$ tabel $=1,96$ maka variabel tersebut berperan sebagai variabel mediasi dalam hubungan antara variabel independen dengan dependen.

\section{HASIL DAN PEMBAHASAN}

Analisis regresi linear berganda dilakukan pada struktur I dan struktur II. Struktur I menggambarkan pengaruh variabel sosial ekonomi dan materialism pada tingkat financial literacy mahasiswa akuntansi. Pengujian dilakukan dengan menggunakan bantuan Software SPSS. Hasil analisis regresi linear berganda pada struktur I yang dilakukan disajikan dalam Tabel 1. 
Tabel 2. Hasil Analisis Regresi Linear Berganda Struktur I

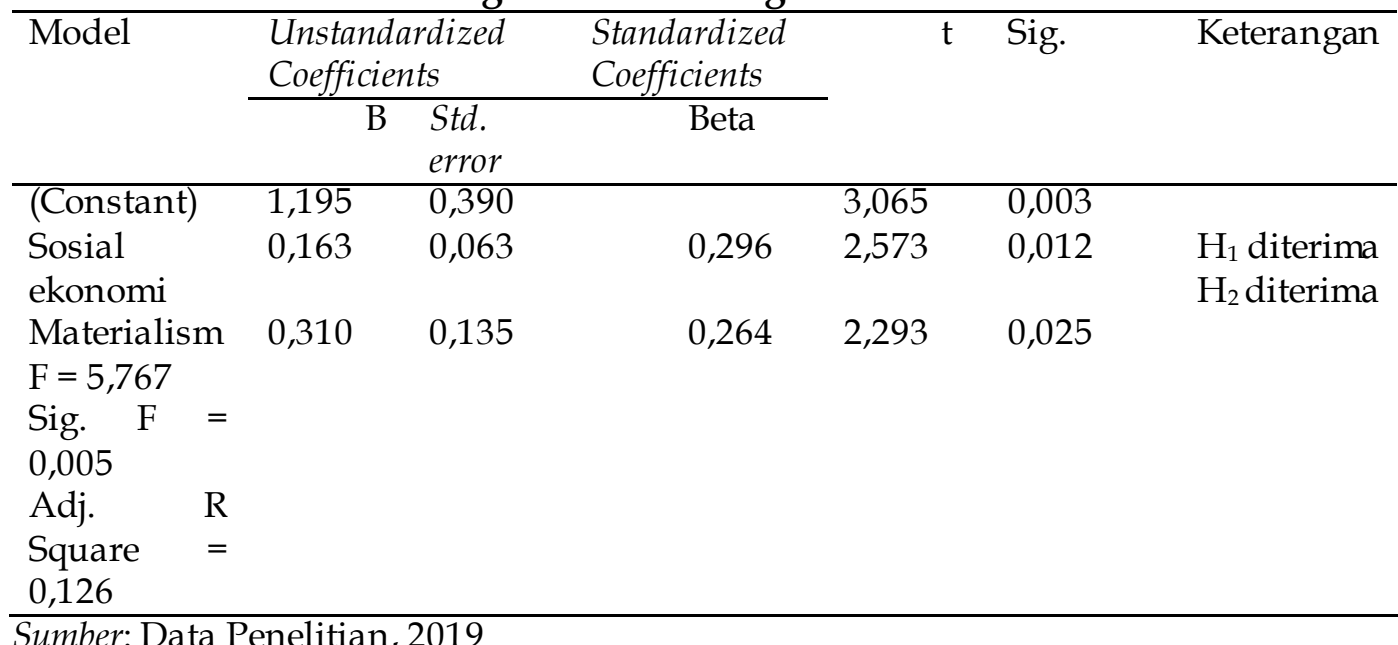

Sumber: Data Penelitian, 2019

Berdasarkan Tabel 2. dapat interpretasikan hasil persamaan regresi yang menunjukkan besarnya pengaruh variabel sosial ekonomi dan materialism pada tingkat financial literacy mahasiswa akuntansi sebagai berikut:

Finlit $=1,195+0,163$ Sosec $+0,310$ Mat $+\varepsilon$

Struktur II menggambarkan pengaruh variabel status sosial ekonomi, materialism, dan tingkat financial literacy pada personal financial behavior mahasiswa akuntansi. Pengujian dilakukan dengan menggunakan bantuan SPSS dengan hasil sebagai berikut:

Tabel 3. Hasil Analisis Regresi Linear Berganda Struktur II

\begin{tabular}{|c|c|c|c|c|c|c|c|}
\hline \multirow[t]{2}{*}{ Model } & \multicolumn{2}{|c|}{$\begin{array}{l}\text { Unstandardized } \\
\text { Coefficients }\end{array}$} & \multirow{2}{*}{$\begin{array}{l}\text { Standardized } \\
\text { Coefficients }\end{array}$} & \multirow[t]{2}{*}{$\mathrm{t}$} & \multirow[t]{2}{*}{ Sig } & & \multirow[t]{2}{*}{ Keterangan } \\
\hline & $\mathrm{B}$ & $\begin{array}{l}\text { Std. } \\
\text { error }\end{array}$ & & & & & \\
\hline (Constant) & 2,105 & 0,228 & & 9,223 & & $\overline{0}$ & \\
\hline Sosial ekonomi & 0,067 & 0,036 & 0,216 & 1,853 & ,000 & & H3 diterima \\
\hline Materialism & 0,149 & 0,077 & 0,225 & 1,943 & & 0 & H4 diterima \\
\hline $\begin{array}{l}\text { Financial literacy } \\
F=6,037\end{array}$ & 0,147 & 0,068 & 0,259 & 2,147 & 069 & 0 & H5 diterima \\
\hline Sig. $F=0,001$ & & & & & ,056 & & \\
\hline Adj. $\mathrm{R}$ Square $=$ & & & & & & 0 & \\
\hline 0,186 & & & & & ,036 & & \\
\hline
\end{tabular}

Sumber: Data Penelitian, 2019

Berdasarkan Tabel 3. dapat interpretasikan hasil persamaan regresi yang menunjukkan besarnya pengaruh variabel sosial ekonomi, materialism dan financial literacy pada personal financial behavior mahasiswa akuntansi sebagai berikut:

$$
\text { Finbehav }=2,105+0,067 \text { Sosec }+0,149 \text { Mat }+0,147 \text { Finlit }+\varepsilon
$$

Berdasarkan Tabel 3., dapat diketahui nilai signifikansi dari variabel status social ekonomi sebesar 0,012, serta signifikansi untuk variabel materialism yakni 0,025, keduanya lebih kecil dari signifikansi 0,05 . Hal ini berarti bahwa semakin tinggi status social ekonomi orang tua mahasiswa dan semakin tinggi sifat materialism maka semakin tinggi tingkat financial literacy mahasiswa akuntansi. 
Tabel 4. Signifikansi Persamaan Struktural I

\begin{tabular}{|c|c|c|c|c|c|}
\hline \multirow[t]{2}{*}{ Model } & \multicolumn{2}{|c|}{$\begin{array}{l}\text { Unstandardized } \\
\text { Coefficients }\end{array}$} & $\begin{array}{l}\text { Standardized } \\
\text { Coefficients }\end{array}$ & $\mathrm{t}$ & Sig \\
\hline & $\mathrm{B}$ & Std.error & Beta & & \\
\hline (Constant) & 1,195 & 0,390 & & 3,065 & 0,003 \\
\hline Sosial ekonomi & 0,163 & 0,063 & 0,296 & 2,573 & 0,012 \\
\hline Materialism & 0,310 & 0,135 & 0,264 & 2,293 & 0,025 \\
\hline
\end{tabular}

Sumber: Data Penelitian, 2019

Besarnya koefisien jalur dan persamaan struktural regresi yang dihasilkan adalah sebagai berikut:

$Y=0,296$ Sosec $+0,264$ Mat $+\varepsilon 1$

Berdasarkan Tabel 4., dapat diketahui nilai standardized coefficiets beta sebesar 0,296 untuk variabel status sosial ekonomi ke tingkat financial literacy pada nilai path P1. Nilai standardized coefficiets beta sebesar 0,264 untuk sifat materialism ke tingkat financial literacy pada nilai path P2.

Berdasarkan Tabel 4., dapat diketahui nilai signifikansi dari variabel status social ekonomi sebesar 0,069 (0,0345 untuk uji satu sisi), signifikansi untuk variabel materialism yakni 0,056 (0,028 untuk uji satu sisi), dan signifikansi financial literacy adalah 0,036. Keseluruhan bernilai lebih kecil dari signifikansi 0,05 . Hal ini berarti bahwa semakin tinggi status social ekonomi orang tua mahasiswa, sifat materialism dan tingkat financial literacy mahasiswa maka semakin baik personal financial behavior mahasiswa akuntansi.

Tabel 5. Signifikansi Persamaan Struktural II

\begin{tabular}{llllll}
\hline Model & \multicolumn{2}{l}{$\begin{array}{l}\text { Unstandardized } \\
\text { Coefficients }\end{array}$} & $\begin{array}{l}\text { Standardized } \\
\text { Coefficients }\end{array}$ & $\mathrm{t}$ Sig \\
\cline { 2 - 4 } & $\mathrm{B}$ & Std. error & Beta & & \\
\hline (Constant) & 2,105 & 0,228 & & 9,223 & 0,000 \\
Sosial ekonomi & 0,067 & 0,036 & 0,216 & 1,853 & 0,069 \\
Materialism & 0,149 & 0,077 & 0,225 & 1,943 & 0,056 \\
Financial literacy & 0,147 & 0,068 & 0,259 & 2,147 & 0,036 \\
\hline
\end{tabular}

Sumber: Data Penelitian, 2019

Besarnya koefisien jalur dan persamaan struktural regresi yang dihasilkan adalah sebagai berikut:

\section{$Z=0,216$ Sosec $+0,225$ Mat $+0,259$ Finlit $+\varepsilon 2$}

Pengaruh total diperoleh dari penjumlahan pengaruh langsung (PL) dan pengaruh tidak langsung (PTL) variabel independen pada variabel dependen. Tabel 6. menjelaskan tentang hasil uji analisis jalur (path analysis) untuk menentukan besarnya pengaruh total variabel status sosial ekonomi dan materialism pada personal financial behavior mahasiswa akuntansi.

Berdasarkan Tabel 5. dapat dijelaskan bahwa variabel status sosial ekonomi berpengaruh langsung pada personal financial behavior mahasiswa akuntansi sebesar 0,216. Variabel status sosial ekonomi juga mempunyai pengaruh tidak langsung pada personal financial behavior mahasiswa akuntansi melalui financial literacy sebesar 0,076. Sehingga besarnya pengaruh total variabel status sosial ekonomi pada personal financial behavior mahasiswa akuntansi melalui financial literacy adalah sebesar 0,292. 
Tabel 6. Hasil Uji Analisis Jalur

\begin{tabular}{lll}
\hline \multicolumn{1}{c}{ Keterangan } & Nilai $\mathrm{p}$ & \multicolumn{1}{c}{ Analisis } \\
\hline $\begin{array}{l}\text { Pengaruh Sosec }(\mathrm{X} 1) \text { ke } \\
\text { Finbehave (Y2) }\end{array}$ & 0,216 & $\begin{array}{l}\text { Pengaruh total variabel } \\
\text { status sosial ekonomipada } \\
\text { personal financial behavior } \\
\text { adalah0,216 }+0,076=0,292\end{array}$ \\
$\begin{array}{l}\text { Pengaruh Sosec }(\mathrm{X} 1) \text { ke } \\
\text { Finbehav (Y2) melalui }\end{array}$ & $0,296^{*} 0,259=0,076$ & $\begin{array}{l}\text { Pengaruh total variabel } \\
\text { sikap materialism pada } \\
\text { Finlit (Y1) }\end{array}$ \\
$\begin{array}{l}\text { Personal financial behavior } \\
\text { Finbehave (Y2) }\end{array}$ & 0,225 & $\begin{array}{l}\text { adalah0,225 + 0.068 }=0,293 \\
\text { Pengaruh Mat (X2) ke } \\
\text { Finbehav (Y2) melalui }\end{array}$ \\
Finlit (Y1)
\end{tabular}

Sumber: Data Penelitian, 2019

Untuk variabel sikap materialism, berpengaruh langsung pada personal financial behavior mahasiswa akuntansi sebesar 0,225. Materialism juga berpengaruh tidak langsung pada personal financial behavior mahasiswa akuntansi sebesar 0,0684 , sehingga besarnya pengaruh total materialism pada personal financial behavior melalui financial literacy adalah 0,293.

Pengujian regresi untuk struktur I menjelaskan pengaruh variabel status sosial ekonomi pada financial literacy mahasiswa akuntansi. Hasil regresi menunjukkan bahwa $\mathrm{H} 1$ diterima artinya semakin tinggi status sosial ekonomi orang tua mahasiswa maka semakin tinggi tingkat financial literacy yang dimiliki mahasiswa. Hasil penelitian ini sejalan dengan temuan penelitian Gutter (2008) menyatakan bahwa mahasiswa yang mempunyai status sosial ekonomi yang tinggi juga mempunyai tingkat pengetahuan, sikap, dan perilaku keuangan yang tinggi. Temuan Aningsih \& Soejoto (2018); Lusardi et al. (2010); Lusardi \& Tufano, 2009; Mitchell, Lusardi, \& Curto (2009) menemukan bahwa tingkat literasi seseorang dipengaruhi oleh tingkat pekerjaan dan status sosial orang tua. Menurut Ahmadi (2007) status sosial ekonomi orang tua mempunyai pengaruh terhadap tingkah laku dan pengalaman anak-anaknya. Seorang mahasiswa yang dibesarkan oleh orang tua yang memiliki tingkat pendapatan yang memadai, pekerjaan yang baik, serta tingkat pendidikan tinggi cenderung mendapatkan pengalaman dan pembelajaran keuangan dengan baik. Latar belakang orang tua, pekerjaan orang tua, jabatan sosial orang tua dapat mempengaruhi sikap seseorang dalam melakukan kegiatan belanja, menabung, investasi, kredit, penganggaran, dan pengelolaan keuangan (Ariyanto, 2020).

Pengujian regresi struktur I juga menjelaskan pengaruh sikap materialism pada tingkat financial literacy mahasiswa akuntansi. Hasil uji regresi menunjukkan bahwa $\mathrm{H}_{2}$ diterima artinya semakin tinggi sifat materialism mahasiswa maka semakin tinggi tingkat financial literacy yang dimiliki mahasiswa. Hasil pengujian ini mendukung temuan penelitian Richins \& Dawson (1992) mengenai pengaruh sifat materialism pada tingkat financial literacy seseorang. Sifat materialistis yang dimiliki individu menyebabkan seseorang untuk cenderung memperkaya dirinya sendiri dengan cara terus menerus menumpuk kekayaan. Tindakan untuk mengumpulkan kekayaan dan 
memperkaya diri sendiri merupakan wujud refleksi dari suatu kesuksesan, kebahagian dan kenikmatan dunia. Sehingga individu akan berusaha untuk mempelajari dan menambah pengetahuan keuangan (financial literacy) yang bermanfaat bagi pengambilan keputusan keuangan. Dalam konteks penelitian ini, seorang mahasiswa yang memiliki sifat materialism yang tinggi memiliki ketertarikan yang lebih besar untuk memperoleh pengetahuan mengenai keuangan sehingga meningkatkan financial literacy yang dimiliki oleh mahasiswa tersebut.

Selanjutnya pengujian regresi struktur II menguji pengaruh financial literacy, status sosial ekonomi dan materialism pada personal financial behavior mahasiswa akuntansi. Hasil uji regresi menunjukkan $\mathrm{H}_{3}$ diterima yakni semakin tinggi tingkat financial literacy mahasiswa akuntansi maka semakin baik personal financial behavior mahasiswa tersebut. Temuan penelitian ini mengkonfirmasi temuan penelitian terdahulu. Literasi keuangan erat kaitannya dengan manajemen keuangan dimana semakin tinggi tingkat literasi keuangan seseorang maka makin baik pula manajemen keuangan seseorang tersebut (Laily, 2016). Chinen \& Endo (2012) mengatakan bahwa individu yang memiliki pengetahuan dan kemampuan untuk membuat keputusan yang benar tentang keuangan tidak akan memiliki masalah keuangan dimasa depan dan menunjukkan perilaku keuangan yang sehat serta mampu menentukan prioritas kebutuhan bukan keinginan. Menurut Kholilah \& Iramani (2013) pengetahuan keuangan adalah dasar faktor kritis dalam pengambilan keputusan keuangan sehingga semakin baik pengetahuan tentang keuangan makin semakin baik pula dalam mengelola keuangan. Mahasiswa adalah individu dengan kemampuan intelektual tinggi, terlebih lagi mahasiswa akuntansi yang telah mendapatkan pengetahuan keuangan melalui mata kuliah Manajemen Keuangan memiliki kemampuan untuk mengelola keuangan pribadi terutama dalam aktivitas konsumsi, investasi dan tabungan.

Hasil uji regresi struktur II juga menunjukkan bahwa $\mathrm{H}_{4}$ diterima yakni semakin tinggi status sosial ekonomi orang tua mahasiswa maka semakin baik personal financial behavior mahasiswa akuntansi. Selaras dengan hasil pengujian ini, menurut Aningsih \& Soejoto (2018) orang tua yang memiliki status sosial lebih tinggi, cenderung memiliki wawasan yang lebih luas, lebih mampu meraih pendapatan yang lebih besar, dan lebih mampu untuk berinteraksi dengan lingkungan sosialnya dibandingkan dengan seseorang yang berstatus sosial ekonomi rendah. Kondisi tersebut memberikan peluang yang lebih besar bagi seorang anak untuk mendapatkan pengalaman keuangan yang lebih baik. Dalam konteks penelitian ini, seorang mahasiswa dengan latar belakang status sosial ekonomi orang tua yang lebih tinggi akan mampu mendapatkan pengalaman dan fasilitas lebih untuk melakukan aktivitas keuangan seperti konsumsi, investasi, kredit dan menabung sehingga mengasah kemampuan mereka dalam mengelola keuangan pribadi sejak dini.

Berdasarkan hasil uji regresi struktur II dapat dipaparkan bahwa H5 diterima, artinya semakin tinggi sifat materialism mahasiswa maka semakin baik personal financial behavior mahasiswa akuntansi. Temuan penelitian ini sejalan dengan hasil penelitian Darpito \& Anwar (2015), yang memaparkan bahwa sifat materialistis yang dimiliki individu menyebabkan seseorang untuk cenderung 
memperkaya dirinya sendiri dengan cara terus menerus menumpuk kekayaan. Tindakan untuk mengumpulkan kekayaan dan memperkaya diri sendiri merupakan wujud refleksi dari suatu kesuksesan, kebahagian dan kenikmatan dunia. Sehingga hal ini mempengaruhi tindakan individu dalam melakukan pengelolaan keuangan dengan lebih cermat dan hati-hati. Seorang mahasiswa yang memiliki sikap materialism tinggi akan cenderung memiliki ketertarikan yang tinggi pada cara-cara menambah penghasilan dan pengelolaan keuangan, sehingga mereka memiliki tingkat personal financial behavior yang lebih baik. Mereka berusaha mengelola uang yang dimiliki agar dapat mencukupi kebutuhan dan juga berusaha menambah sumber-sumber penghasilan.

Hipotesis 6 dan hipotesis 7 terkait dengan peran financial literacy sebagai varibel mediasi. Berdasarkan hasil uji Sobel, H6 diterima, artinya semakin tinggi status sosial ekonomi orang tua mahasiwa maka personal financial behavior mahasiswa semakin baik melalui peningkatan financial literacy mahasiswa. Perilaku keuangan yang sehat ditunjukkan oleh aktivitas perencanaan, pengelolaan serta pengendalian keuangan yang baik. Indikator perilaku keuangan yang baik dapat dilihat dari cara atau sikap seseorang dalam mengelola keluar masuknya uang, manajemen kredit, tabungan dan investasi (Hilgert \& Hogarth, 2003). Bijak tidaknya pengelolaan keuangan pribadi ini erat kaitannya dengan kemampuan serta pengetahuan seseorang akan konsepkonsep keuangan yang dikenal dengan financial literacy. Pembentukan financial literacy dapat dilakukan melalui lingkungan keluarga maupun lingkungan perguruan tinggi (Widyawati, 2012). Di dalam lingkungan keluarga, tingkat financial literacy ditentukan oleh peran orang tua dalam memberikan dukungan berupa pendidikan keuangan dalam keluarga. Pendidikan pengelolaan keuangan di dalam keluarga dipengaruhi oleh status sosial ekonomi orang tua dalam hal ini adalah besarnya pendapatan orang tua. Dengan latar belakang status sosial orang tua yang memiliki pendapatan yang tinggi, mampu memberikan kesempatan bagi mahasiswa untuk memperoleh pengalaman pengelolaan keuangan yang lebih baik sehingga mendorong peningkatan pengetahuan keuangan yang dimiliki. Pengalaman tersebut akan menjadi kebiasaan bagi mereka sehingga pola pengelolaan keuangan pribadi (personal financial behavior) sudah terbentuk sejak dini dan mempengaruhi perilaku keuangan mereka saat ini.

Hasil pengujian Sobel juga menemukan bahwa financial literacy bukan merupakan variabel mediasi pada pengaruh tidak langsung sikap materialism pada personal financial behavior. Dengan demikian $\mathrm{H}_{7}$ ditolak. Secara teori sikap materialism mendorong individu untuk lebih cermat dalam pengelolaan keuangan serta memberikan stimulus bagi mereka untuk menambah pengetahuan terkait dengan keuangan seperti pengetahuan umum keuangan, tabungan dan pinjaman, asuransi dan investasi. Namun hasil temuan penelitian ini menjelaskan jika sikap materialism tidak dapat mendorong mahasiswa untuk mengelola keuangan pribadi dengan baik.

\section{SIMPULAN}

Analisis regresi linear berganda dilakukan pada struktur I dan struktur II. Struktur I menggambarkan pengaruh variabel sosial ekonomi dan materialism 
pada tingkat financial literacy mahasiswa akuntansi. Pengujian dilakukan dengan menggunakan bantuan Software SPSS. Hasil analisis regresi linear berganda pada struktur I yang dilakukan disajikan dalam Tabel 1.

Tabel 2. Hasil Analisis Regresi Linear Berganda Struktur I

\begin{tabular}{|c|c|c|c|c|c|c|}
\hline \multirow[t]{2}{*}{ Model } & \multicolumn{2}{|c|}{$\begin{array}{l}\text { Unstandardized } \\
\text { Coefficients }\end{array}$} & $\begin{array}{l}\text { Standardized } \\
\text { Coefficients }\end{array}$ & \multirow[t]{2}{*}{$t$} & \multirow[t]{2}{*}{ Sig. } & \multirow[t]{2}{*}{ Keterangan } \\
\hline & $\mathrm{B}$ & $\begin{array}{l}\text { Std. } \\
\text { error }\end{array}$ & Beta & & & \\
\hline (Constant) & 1,195 & 0,390 & & 3,065 & 0,003 & \\
\hline $\begin{array}{l}\text { Sosial } \\
\text { ekonomi }\end{array}$ & 0,163 & 0,063 & 0,296 & 2,573 & 0,012 & $\begin{array}{l}\mathrm{H}_{1} \\
\text { diterima }\end{array}$ \\
\hline $\begin{array}{l}\text { Materialism } \\
\mathrm{F}=5,767\end{array}$ & 0,310 & 0,135 & 0,264 & 2,293 & 0,025 & $\mathrm{H}_{2}$ diterima \\
\hline $\begin{array}{l}\text { Sig. } \quad F= \\
0,005\end{array}$ & & & & & & \\
\hline Adj. & & & & & & \\
\hline $\begin{array}{l}\text { Square }= \\
0,126\end{array}$ & & & & & & \\
\hline
\end{tabular}

Berdasarkan Tabel 2. dapat interpretasikan hasil persamaan regresi yang menunjukkan besarnya pengaruh variabel sosial ekonomi dan materialism pada tingkat financial literacy mahasiswa akuntansi sebagai berikut:

Finlit $=1,195+0,163$ Sosec $+0,310$ Mat $+\varepsilon$

Struktur II menggambarkan pengaruh variabel status sosial ekonomi, materialism, dan tingkat financial literacy pada personal financial behavior mahasiswa akuntansi. Pengujian dilakukan dengan menggunakan bantuan SPSS dengan hasil sebagai berikut:

Tabel 3. Hasil Analisis Regresi Linear Berganda Struktur II

\begin{tabular}{|c|c|c|c|c|c|c|c|}
\hline \multirow[t]{2}{*}{ Model } & \multicolumn{2}{|c|}{$\begin{array}{l}\text { Unstandardized } \\
\text { Coefficients }\end{array}$} & \multirow{2}{*}{$\begin{array}{c}\begin{array}{l}\text { Standardized } \\
\text { Coefficients }\end{array} \\
\text { Beta }\end{array}$} & \multirow[t]{2}{*}{$\mathrm{t}$} & \multirow[t]{2}{*}{ Sig } & & \multirow[t]{2}{*}{ Keterangan } \\
\hline & $\begin{array}{l}\mathrm{B} \\
\end{array}$ & $\begin{array}{l}\text { Std. } \\
\text { error }\end{array}$ & & & & & \\
\hline (Constant) & 2,105 & 0,228 & & 9,223 & & 0 & \\
\hline Sosial ekonomi & 0,067 & 0,036 & 0,216 & 1,853 & ,000 & & H3 diterima \\
\hline Materialism & 0,149 & 0,077 & 0,225 & 1,943 & & 0 & H4 diterima \\
\hline $\begin{array}{l}\text { Financial literacy } \\
F=6,037\end{array}$ & 0,147 & 0,068 & 0,259 & 2,147 & 069 & 0 & H5 diterima \\
\hline Sig. $F=0,001$ & & & & & ,056 & & \\
\hline $\begin{array}{l}\text { Adj. } R \text { Square }= \\
0,186\end{array}$ & & & & & 036 & 0 & \\
\hline
\end{tabular}

Sumber: Data Penelitian, 2019

Berdasarkan Tabel 3. dapat inter pretasikan hasil persamaan regresi yang menunjukkan besarnya pengaruh variabel sosial ekonomi, materialism dan financial literacy pada personal financial behavior mahasiswa akuntansi sebagai berikut:

$$
\text { Finbehav }=2,105+0,067 \text { Sosec }+0,149 \text { Mat }+0,147 \text { Finlit }+\varepsilon
$$

Berdasarkan Tabel 3., dapat diketahui nilai signifikansi dari variabel status social ekonomi sebesar 0,012, serta signifikansi untuk variabel materialism yakni 0,025, keduanya lebih kecil dari signifikansi 0,05 . Hal ini berarti bahwa semakin tinggi 
status social ekonomi orang tua mahasiswa dan semakin tinggi sifat materialism maka semakin tinggi tingkat financial literacy mahasiswa akuntansi.

Tabel 4. Signifikansi Persamaan Struktural I

\begin{tabular}{|c|c|c|c|c|c|}
\hline \multirow[t]{2}{*}{ Model } & \multicolumn{2}{|c|}{$\begin{array}{l}\text { Unstandardized } \\
\text { Coefficients }\end{array}$} & $\begin{array}{l}\text { Standardized } \\
\text { Coefficients }\end{array}$ & ( & Sig \\
\hline & $\mathrm{B}$ & Std.error & Beta & & \\
\hline (Constant) & 1,195 & 0,390 & & 3,065 & 0,003 \\
\hline Sosial ekonomi & 0,163 & 0,063 & 0,296 & 2,573 & 0,012 \\
\hline Materialism & 0,310 & 0,135 & 0,264 & 2,293 & 0,025 \\
\hline
\end{tabular}

Sumber: Data Penelitian, 2019

Besarnya koefisien jalur dan persamaan struktural regresi yang dihasilkan adalah sebagai berikut:

\section{$Y=0,296$ Sosec $+0,264$ Mat $+\varepsilon 1$}

Berdasarkan Tabel 4., dapat diketahui nilai standardized coefficiets beta sebesar 0,296 untuk variabel status sosial ekonomi ke tingkat financial literacy pada nilai path P1. Nilai standardized coefficiets beta sebesar 0,264 untuk sifat materialism ke tingkat financial literacy pada nilai path P2.

Berdasarkan Tabel 4., dapat diketahui nilai signifikansi dari variabel status social ekonomi sebesar 0,069 (0,0345 untuk uji satu sisi), signifikansi untuk variabel materialism yakni 0,056 (0,028 untuk uji satu sisi), dan signifikansi financial literacy adalah 0,036. Keseluruhan bernilai lebih kecil dari signifikansi 0,05 . Hal ini berarti bahwa semakin tinggi status social ekonomi orang tua mahasiswa, sifat materialism dan tingkat financial literacy mahasiswa maka semakin baik personal financial behavior mahasiswa akuntansi.

Tabel 5. Signifikansi Persamaan Struktural II

\begin{tabular}{llllll}
\hline Model & \multicolumn{2}{l}{$\begin{array}{l}\text { Unstandardized } \\
\text { Coefficients }\end{array}$} & $\begin{array}{l}\text { Standardized } \\
\text { Coefficients }\end{array}$ & $\mathrm{t}$ Sig \\
\cline { 2 - 4 } & $\mathrm{B}$ & Std.error & Beta & & \\
\hline (Constant) & 2,105 & 0,228 & & 9,223 & 0,000 \\
Sosial ekonomi & 0,067 & 0,036 & 0,216 & 1,853 & 0,069 \\
Materialism & 0,149 & 0,077 & 0,225 & 1,943 & 0,056 \\
Financial literacy & 0,147 & 0,068 & 0,259 & 2,147 & 0,036 \\
\hline
\end{tabular}

Sumber: Data Diolah, (2019)

Besarnya koefisien jalur dan persamaan struktural regresi yang dihasilkan adalah sebagai berikut:

\section{$Z=0,216$ Sosec $+0,225$ Mat $+0,259$ Finlit $+\varepsilon 2$}

Pengaruh total diperoleh dari penjumlahan pengaruh langsung (PL) dan pengaruh tidak langsung (PTL) variabel independen pada variabel dependen. Tabel 6. menjelaskan tentang hasil uji analisis jalur (path analysis) untuk menentukan besarnya pengaruh total variabel status sosial ekonomi dan materialism pada personal financial behavior mahasiswa akuntansi.

Berdasarkan Tabel 5. dapat dijelaskan bahwa variabel status sosial ekonomi berpengaruh langsung pada personal financial behavior mahasiswa akuntansi sebesar 0,216. Variabel status sosial ekonomi juga mempunyai pengaruh tidak langsung pada personal financial behavior mahasiswa akuntansi melalui financial literacy sebesar 0,076. Sehingga besarnya pengaruh total variabel status sosial ekonomi pada personal financial behavior mahasiswa akuntansi melalui financial literacy adalah sebesar 0,292. 
Tabel 6. Hasil Uji Analisis Jalur

\begin{tabular}{|c|c|c|c|}
\hline \multicolumn{2}{|l|}{ Keterangan } & Nilai $p$ & Analisis \\
\hline $\begin{array}{l}\text { Pengaruh Sosec } \\
\text { Finbehave (Y2) }\end{array}$ & (X1) ke & 0,216 & $\begin{array}{l}\text { Pengaruh total variabel } \\
\text { status sosial ekonomipada } \\
\text { personal financial behavior }\end{array}$ \\
\hline $\begin{array}{ll}\text { Pengaruh } & \text { Sosec } \\
\text { Finbehav } & \text { (Y2) } \\
\text { Finlit (Y1) } & \end{array}$ & $\begin{array}{l}(\mathrm{X} 1) \mathrm{ke} \\
\text { melalui }\end{array}$ & $0,296^{*} 0,259=0,076$ & $\begin{array}{l}\text { adalah } 0,216+0,076= \\
0,292\end{array}$ \\
\hline $\begin{array}{l}\text { Pengaruh Mat } \\
\text { Finbehave (Y2) }\end{array}$ & (X2) ke & 0,225 & $\begin{array}{l}\text { Pengaruh total variabel } \\
\text { sikap materialism pada } \\
\text { personal financial behavior }\end{array}$ \\
\hline $\begin{array}{ll}\text { Pengaruh } & \text { Mat } \\
\text { Finbehav } & (\mathrm{Y} 2) \\
\text { Finlit (Y1) } & \end{array}$ & $\begin{array}{l}(\mathrm{X} 2) \mathrm{ke} \\
\text { melalui }\end{array}$ & $0,264^{*} 0,259=0,068$ & $\begin{array}{l}\text { adalah } 0,225+0.068= \\
0,293\end{array}$ \\
\hline
\end{tabular}

Sumber: Data Penelitian, 2019

Untuk variabel sikap materialism, berpengaruh langsung pada personal financial behavior mahasiswa akuntansi sebesar 0,225. Materialism juga berpengaruh tidak langsung pada personal financial behavior mahasiswa akuntansi sebesar 0,0684, sehingga besarnya pengaruh total materialism pada personal financial behavior melalui financial literacy adalah 0,293.

Pengujian regresi untuk struktur I menjelaskan pengaruh variabel status sosial ekonomi pada financial literacy mahasiswa akuntansi. Hasil regresi menunjukkan bahwa $\mathrm{H}_{1}$ diterima artinya semakin tinggi status sosial ekonomi orang tua mahasiswa maka semakin tinggi tingkat financial literacy yang dimiliki mahasiswa. Hasil penelitian ini sejalan dengan temuan penelitian Gutter (2008) menyatakan bahwa mahasiswa yang mempunyai status sosial ekonomi yang tinggi juga mempunyai tingkat pengetahuan, sikap, dan perilaku keuangan yang tinggi. Temuan Aningsih \& Soejoto (2018), Lusardi et al. (2010), Lusardi \& Tufano, (2009), dan Mitchell, Lusardi, \& Curto (2009) menemukan bahwa tingkat literasi seseorang dipengaruhi oleh tingkat pekerjaan dan status sosial orang tua. Menurut Ahmadi (2007) status sosial ekonomi orang tua mempunyai pengaruh terhadap tingkah laku dan pengalaman anak-anaknya. Seorang mahasiswa yang dibesarkan oleh orang tua yang memiliki tingkat pendapatan yang memadai, pekerjaan yang baik, serta tingkat pendidikan tinggi cenderung mendapatkan pengalaman dan pembelajaran keuangan dengan baik. Latar belakang orang tua, pekerjaan orang tua, jabatan sosial orang tua dapat mempengaruhi sikap seseorang dalam melakukan kegiatan belanja, menabung, investasi, kredit, penganggaran, dan pengelolaan keuangan (Ariyanto, 2020).

Pengujian regresi struktur I juga menjelaskan pengaruh sikap materialism pada tingkat financial literacy mahasiswa akuntansi. Hasil uji regresi menunjukkan bahwa $\mathrm{H}_{2}$ diterima artinya semakin tinggi sifat materialism mahasiswa maka semakin tinggi tingkat financial literacy yang dimiliki mahasiswa. Hasil pengujian ini mendukung temuan penelitian Richins \& Dawson (1992) mengenai pengaruh sifat materialism pada tingkat financial literacy seseorang. Sifat materialistis yang dimiliki individu menyebabkan seseorang untuk cenderung memperkaya dirinya sendiri dengan cara terus menerus menumpuk kekayaan. Tindakan untuk mengumpulkan kekayaan dan 
memperkaya diri sendiri merupakan wujud refleksi dari suatu kesuksesan, kebahagian dan kenikmatan dunia. Sehingga individu akan berusaha untuk mempelajari dan menambah pengetahuan keuangan (financial literacy) yang bermanfaat bagi pengambilan keputusan keuangan. Dalam konteks penelitian ini, seorang mahasiswa yang memiliki sifat materialism yang tinggi memiliki ketertarikan yang lebih besar untuk memperoleh pengetahuan mengenai keuangan sehingga meningkatkan financial literacy yang dimiliki oleh mahasiswa tersebut.

Selanjutnya pengujian regresi struktur II menguji pengaruh financial literacy, status sosial ekonomi dan materialism pada personal financial behavior mahasiswa akuntansi. Hasil uji regresi menunjukkan $\mathrm{H}_{3}$ diterima yakni semakin tinggi tingkat financial literacy mahasiswa akuntansi maka semakin baik personal financial behavior mahasiswa tersebut. Temuan penelitian ini mengkonfirmasi temuan penelitian terdahulu. Literasi keuangan erat kaitannya dengan manajemen keuangan dimana semakin tinggi tingkat literasi keuangan seseorang maka makin baik pula manajemen keuangan seseorang tersebut (Laily, 2016). Chinen \& Endo (2012) mengatakan bahwa individu yang memiliki pengetahuan dan kemampuan untuk membuat keputusan yang benar tentang keuangan tidak akan memiliki masalah keuangan dimasa depan dan menunjukkan perilaku keuangan yang sehat serta mampu menentukan prioritas kebutuhan bukan keinginan. Menurut Kholilah \& Iramani (2013) pengetahuan keuangan adalah dasar faktor kritis dalam pengambilan keputusan keuangan sehingga semakin baik pengetahuan tentang keuangan makin semakin baik pula dalam mengelola keuangan. Mahasiswa adalah individu dengan kemampuan intelektual tinggi, terlebih lagi mahasiswa akuntansi yang telah mendapatkan pengetahuan keuangan melalui mata kuliah Manajemen Keuangan memiliki kemampuan untuk mengelola keuangan pribadi terutama dalam aktivitas konsumsi, investasi dan tabungan.

Hasil uji regresi struktur II juga menunjukkan bahwa $\mathrm{H}_{4}$ diterima yakni semakin tinggi status sosial ekonomi orang tua mahasiswa maka semakin baik personal financial behavior mahasiswa akuntansi. Selaras dengan hasil pengujian ini, menurut Aningsih \& Soejoto (2018) orang tua yang memiliki status sosial lebih tinggi, cenderung memiliki wawasan yang lebih luas, lebih mampu meraih pendapatan yang lebih besar, dan lebih mampu untuk berinteraksi dengan lingkungan sosialnya dibandingkan dengan seseorang yang berstatus sosial ekonomi rendah. Kondisi tersebut memberikan peluang yang lebih besar bagi seorang anak untuk mendapatkan pengalaman keuangan yang lebih baik. Dalam konteks penelitian ini, seorang mahasiswa dengan latar belakang status sosial ekonomi orang tua yang lebih tinggi akan mampu mendapatkan pengalaman dan fasilitas lebih untuk melakukan aktivitas keuangan seperti konsumsi, investasi, kredit dan menabung sehingga mengasah kemampuan mereka dalam mengelola keuangan pribadi sejak dini.

Berdasarkan hasil uji regresi struktur II dapat dipaparkan bahwa H5 diterima, artinya semakin tinggi sifat materialism mahasiswa maka semakin baik personal financial behavior mahasiswa akuntansi. Temuan penelitian ini sejalan dengan hasil penelitian Darpito \& Anwar (2015), yang memaparkan bahwa sifat materialistis yang dimiliki individu menyebabkan seseorang untuk cenderung 
memperkaya dirinya sendiri dengan cara terus menerus menumpuk kekayaan. Tindakan untuk mengumpulkan kekayaan dan memperkaya diri sendiri merupakan wujud refleksi dari suatu kesuksesan, kebahagian dan kenikmatan dunia. Sehingga hal ini mempengaruhi tindakan individu dalam melakukan pengelolaan keuangan dengan lebih cermat dan hati-hati. Seorang mahasiswa yang memiliki sikap materialism tinggi akan cenderung memiliki ketertarikan yang tinggi pada cara-cara menambah penghasilan dan pengelolaan keuangan, sehingga mereka memiliki tingkat personal financial behavior yang lebih baik. Mereka berusaha mengelola uang yang dimiliki agar dapat mencukupi kebutuhan dan juga berusaha menambah sumber-sumber penghasilan.

Hipotesis 6 dan hipotesis 7 terkait dengan peran financial literacy sebagai varibel mediasi. Berdasarkan hasil uji Sobel, H6 diterima, artinya semakin tinggi status sosial ekonomi orang tua mahasiwa maka personal financial behavior mahasiswa semakin baik melalui peningkatan financial literacy mahasiswa. Perilaku keuangan yang sehat ditunjukkan oleh aktivitas perencanaan, pengelolaan serta pengendalian keuangan yang baik. Indikator perilaku keuangan yang baik dapat dilihat dari cara atau sikap seseorang dalam mengelola keluar masuknya uang, manajemen kredit, tabungan dan investasi (Hilgert \& Hogarth, 2003). Bijak tidaknya pengelolaan keuangan pribadi ini erat kaitannya dengan kemampuan serta pengetahuan seseorang akan konsepkonsep keuangan yang dikenal dengan financial literacy. Pembentukan financial literacy dapat dilakukan melalui lingkungan keluarga maupun lingkungan perguruan tinggi (Widyawati, 2012). Di dalam lingkungan keluarga, tingkat financial literacy ditentukan oleh peran orang tua dalam memberikan dukungan berupa pendidikan keuangan dalam keluarga. Pendidikan pengelolaan keuangan di dalam keluarga dipengaruhi oleh status sosial ekonomi orang tua dalam hal ini adalah besarnya pendapatan orang tua. Dengan latar belakang status sosial orang tua yang memiliki pendapatan yang tinggi, mampu memberikan kesempatan bagi mahasiswa untuk memperoleh pengalaman pengelolaan keuangan yang lebih baik sehingga mendorong peningkatan pengetahuan keuangan yang dimiliki. Pengalaman tersebut akan menjadi kebiasaan bagi mereka sehingga pola pengelolaan keuangan pribadi (personal financial behavior) sudah terbentuk sejak dini dan mempengaruhi perilaku keuangan mereka saat ini.

Hasil pengujian Sobel juga menemukan bahwa financial literacy bukan merupakan variabel mediasi pada pengaruh tidak langsung sikap materialism pada personal financial behavior. Dengan demikian $\mathrm{H}_{7}$ ditolak. Secara teori sikap materialism mendorong individu untuk lebih cermat dalam pengelolaan keuangan serta memberikan stimulus bagi mereka untuk menambah pengetahuan terkait dengan keuangan seperti pengetahuan umum keuangan, tabungan dan pinjaman, asuransi dan investasi. Namun hasil temuan penelitian ini menjelaskan jika sikap materialism tidak dapat mendorong mahasiswa untuk mengelola keuangan pribadi dengan baik.

\section{REFERENSI}

Ahmadi, A. (2007). Psikologi Sosial. Jakarta: Rineka Cipta.

Ajzen, I. (1991). The theory of planned behavior. Organizational Behavior and 
Human Decision Processes, 50(2), 179-211. https://doi.org/10.1016/07495978(91)90020-T

Aningsih, A. ., \& Soejoto, A. (2018). Pengaruh Status Sosial Ekonomi Orang Tua dan Hasil Belajar Mahasiswa terhadap Tingkat Literasi Ekonomi Mahasiswa. Jurnal Pendidikan Ekonomi, Manajemen Dan Keuangan, 2(2), 11-18.

Ariyanto, D. (2020). Influence of justice, culture and love of money towards ethical perception on tax evasion with gender as moderating variable. Journal of Money Laundering Control, 23(1), 245-266. https://doi.org/10.1108/JMLC-06-2019-0047

Case, K. E. (2007). Prinsip-prinsip Ekonomi (Edisi Kede). New Jersey: Pearson Education.

Chen, H., \& Volpe, R. P. (1998). An Analysis of Personal Literacy among College Students. Financial Service Review, 2(7), 107.

Chinen, K., \& Endo, H. (2012). Effect of Attitude and Bacground on Personal Finance Ability: A Student Survey in the United State. International Journal of Management, 29(1), 33-45.

Danes, S. M., \& Haberman, H. R. (2007). Teen financial knowledge, self-efficacy, and behavior: A gendered view. Journal of Financial Counseling and Planning, 18(2), 48-60.

Darpito, S. H., \& Anwar, C. (2015). Transformation Malaysia Indonesia Relation: Towards Asean Community. In Proceeding International Conference and Call of paper (pp. 171-185).

Grohmann, A., Kouwenberg, R., \& Menkhoff, L. (2015). Childhood roots of financial literacy. Journal of Economic Psychology, 51(December), 114-133. https://doi.org/10.1016/j.joep.2015.09.002

Gutter, M. (2008). Financial Managemen Perticies of Colage Student with varying Education Mandates. Denver, Colo: National Endowment for Financial Education.

Herawati, N. T., Candiasa, I. M., Yadnyana, I. K., \& Suharsono, N. (2018). Factors That Influence Financial Behavior Among Accounting Students in Bali. International Journal of Business Administration, 9(3). https://doi.org/10.5430/ijba.v9n3p30

Herdjiono, I., \& Damanik, L. A. (2016). Pengaruh Financial Atti Tude, Financial Knowledge, Parental Income Terhadap Financial Management Behavior. Manajemen Teori Dan Terapan, 9(3).

Hilgert, M. A., \& Hogarth, J. M. (2003). The Connection between Knowledge and Behavior. Household Financial Management, (July), 309-322. https://doi.org/10.15381/rivep.v20i2.609

Ida dan Cinthia Yohana Dwinta. (2010). Pengaruh Locus of Control, Financial Knowledge, Income Terhadap Financial Management Behavior. Jurnal Bisnis Dan Akuntansi, 12(3), 131 - 144.

Kholilah, N. Al, \& Iramani, R. (2013). Studi Financial Management Behavior Pada Masyarakat Surabaya. Journal of Business and Banking, 3(1), 69 - 80. https://doi.org/10.14414/jbb.v3i1.255

Laily, N. (2016). Pengaruh Literasi Keuangan Terhadap Perilaku Mahasiswa Dalam Mengelola Keuangan. Journal of Accounting and Business Education, 1(4), 277-285. https://doi.org/10.26675/jabe.v1i4.6042 
Lusardi, A., Mitchell, O. S., \& Curto, V. (2010). Financial literacy among the young. Journal of Consumer Affairs, 34(2). https://doi.org/10.1111/j.17456606.2010.01173.x

Lusardi, A., \& Tufano, P. (2009). Debt literacy, financial experiences, and overindebtedness. Journal of Pension Economics and Finance, (March), 1-44. https://doi.org/10.1017/S1474747215000232

Mankiw, N. G. (2003). Pengantar Ekonomi (2nd Editio). Jakarta: Erlangga.

Mitchell, O. S., Lusardi, A., \& Curto, V. (2009). Financial Literacy Among the Young: Evidence and Implications for Consumer Policy. National Bureau of Economic Research, 34. https://doi.org/10.2139/ssrn.1459141

Noor, H. F. (2009). Investasi, Pengelolaan Keuangan Bisnis, dan Pengembangan Ekonomi Masyarakat. Jakarta: Indeks.

Nye, P., \& Hillyard, C. (2013). Personal Financial Behavior: The Influence of Quantitative Literacy and Material Values. Numeracy, 6(1), 1-24. https://doi.org/10.5038/1936-4660.6.1.3

Richins, M. L. (2004). The Material Values Scale: Measurement Properties and Development of a Short Form. Journal of Consumer Research, 31, 209-219. https://doi.org/10.1086/383436

Richins, M. L., \& Dawson, S. (1992). A Consumer Values Orientation for Materialism and Its Measurement: Scale Development and Validation. Journal of Consumer Research, 19, 303-316. https://doi.org/10.1086/209304

Soekanto, S. (2010). Sosiologi Suatu Pengantar. Jakarta: Raja Grafindo Persada.

Somer, L. (2011). The theory Of Planned Behavior And The Impact of Past Behavior. The International Business \& Economics Research Journal, 10(1). https://doi.org/10.19030/iber.v10i1.930

Suryanto. (2017). Pola Perilaku Keuangan Mahasiswa Di Perguruan Tinggi. Jurnal Ilmu Politik Dan Komunikasi, VII(Juli).

Widyawati, I. (2012). Faktor-Faktor Yang Mempengaruhi Literasi Finansial Mahasiswa Fakultas Ekonomi Dan Bisnis Universitas Brawijaya. Assets: Jurnal Akuntansi Dan Pendidikan, 1(1), 89-99. https://doi.org/10.25273/jap.v1i1.527 